Article

\title{
Significant baseflow reduction in the Sao Francisco River Basin
}

\author{
Murilo C. Lucas ${ }^{1 *}$, Natalya Kublik ${ }^{2}$, Dulce B. B. Rodrigues ${ }^{3}$, Antonio A. Meira Neto ${ }^{4}$, André \\ Almagro $^{3}$, Davi de C. D. Melo ${ }^{5}$, Samuel C. Zipper ${ }^{6}$ and Paulo Tarso S. Oliveira ${ }^{3}$ \\ 1 Department of Civil Engineering, Federal University of Technology-Paraná, 85502-970, Paraná State, \\ Brazil; muriloclucas@gmail.com (M.C.L.); https://orcid.org/0000-0002-1732-0241. \\ 2 The Polytechnic School, Arizona State University, Tempe, AZ 85212, USA; natalya.kublik@asu.edu (N.K.); \\ https://orcid.org/0000-0003-0377-8750. \\ 3 Federal University of Mato Grosso do Sul, 79070-900, Mato Grosso do Sul State, Brazil; \\ dulcebbr@gmail.com (D.B.B.R.); https://orcid.org/0000-0001-9637-5250; \\ andre.almagro@gmail.com (A.A.); https://orcid.org/0000-0002-3822-4865; \\ paulotarsoms@gmail.com (P.T.S.O.); http://orcid.org/0000-0003-2806-0083. \\ 4 Department of Hydrology and Atmospheric Sciences, University of Arizona, Tucson, AZ 85719, USA; \\ aamneto@email.arizona.edu (A.A.M.N.); https://orcid.org/0000-0002-7508-8241. \\ 5 Department of Soils and Rural Engineering, Federal University of Paraíba, 58397-000, Paraíba State, Brazil; \\ melo.dcd@gmail.com (D.C.D.M.); https://orcid.org/0000-0002-0098-5095. \\ 6 Kansas Geological Survey, University of Kansas, Lawrence, KS 66047, USA; samzipper@ku.edu (S.C.Z.); \\ https://orcid.org/0000-0002-8735-5757. \\ * Correspondence: muriloclucas@gmail.com; Tel.: +55-46-99106-6195 (M.C.L.)
}

Received: date; Accepted: date; Published: date

\begin{abstract}
Water scarcity is a key challenge to global development. In Brazil, the Sao Francisco River Basin (SFB) has experienced water scarcity problems because of decreasing streamflow and increasing demands from multiple sectors. However, the drivers of decreased streamflow, particularly the potential role of surface-groundwater interaction, have not been yet investigated. Here, we assess long-term trends in baseflow, quickflow, and streamflow of the SFB during 19802015 and constrain the most likely drivers of observed decreases through trend analysis of precipitation (P), evapotranspiration (ET), and terrestrial water storage change (TWS). We found that over $82 \%$ of the observed decrease in streamflow can be attributed to a significant decreasing baseflow trend $\left(<-20 \mathrm{~m}^{3} \mathrm{~s}^{-1} \mathrm{y}^{-1}\right)$ along the SFR with spatial agreement between decreased baseflow, increased ET, and irrigated agricultural land. We also noted a decrease in TWS across the SFB with trends exceeding $-20 \mathrm{~mm} \mathrm{y}^{-1}$. Overall, our findings indicate that decreasing groundwater contributions (i.e., baseflow) is providing the observed reduction in total SFR flow. A lack of significant $\mathrm{P}$ trends indicates that only $\mathrm{P}$ variability likely has not caused the observed baseflow reduction, mainly in the Middle and Sub-middle SFB. Therefore, groundwater and surface withdrawals may be likely a driver of water scarcity over the SFB.
\end{abstract}

Keywords: Streamflow depletion, trend analysis, irrigation, land use change, GRACE, water scarcity.

\section{Introduction}

The World Economic Forum has categorized water crises as one of the top-ranked global (severe) risks since 2012 [1], and water is increasingly becoming a priority policy issue at global scales [2]. Ensuring global access to freshwater is one of the United Nations Sustainable Development Goals (SDGs) addressed in the 2030 Agenda [3]. To fulfill the 2030 Agenda, decisionmakers face the complex challenge of balancing water resource availability and water demands [2,4]. Unfortunately, the imbalance between water supply and demand has led to water scarcity [5]. In fact, there is 
increasing trend in water scarcity worldwide [6] triggered in many locations by the increase anthropogenic water use [7].

Streamflow reduction is one manifestation of water scarcity [8]. Hence, understanding how human activities alter streamflow is vital to understand and manage future water scarcity $[9,10]$. Globally, long-term annual average streamflow has decreased by $2.7 \%$, and monthly low flows have decreased, on average, by $57 \%$ on $26 \%$ of global land area because of increasing water abstractions and human water use [11]. Exacerbating these challenges, climate change (i.e., changes in precipitation and temperature) has also potential to alter river flow across the world [12-15].

Water scarcity can also manifest itself in the form of persistent groundwater depletion (or overexploitation) [16]. Persistent groundwater depletion has widely been reported in both regionally and [17-24], and quantifying groundwater depletion has been facilitated by the advent of the Terrestrial Water Storage (TWS) product measured by the Gravity Recovery and Climate Experiment (GRACE) satellite [25]. Additionally, groundwater withdrawals can decrease river flow where the stream and aquifer are hydraulically connected [26], a phenomenon known as streamflow depletion [27-29]. Globally, groundwater withdrawals are high and environmental streamflow limits are known to be severely exceeded in many locations [30], showing that groundwater use has increased water scarcity.

In Brazil, the Sao Francisco River Basin (SFB) has an national strategic importance due to its potential for agriculture, hydropower electricity, urban and industrial water supply and tourism [31]. The Sao Francisco River (SFR) is popularly called "the river of national integration" because crosses a variety of biomes, climates (including the semiarid region), landscapes and socioeconomic status throughout its extension, linking the southeast and northeast Brazil. The SFR is the fourth longest river in the Latin America. The SFB has faced serious water-related problems because of water conflicts for multiple uses and particularly importance for food production by irrigation. As the interaction between surface water and groundwater has often been neglected, the Brazilian government and press have attributed the decrease in streamflow solely to natural dry weather and/or droughts over the SFB. The premise behind this argument is that low precipitation conditions are the sole driver of decreasing flow in the SFR. However, the potential impact of groundwater withdrawals within the SFB on flow in the SFR has not been evaluated.

This paper addresses for the first time some important issues pertaining to the SFR: we start by assessing whether there are significant decreases in streamflow in the SFR. After that, we investigate how baseflow are related to the observed SFR trends. Finally, we analyze the spatial and temporal patterns of climatic drivers and water storage at the SFR in order to understand the role of climate and groundwater withdrawals (demand driven) in explaining the observed trends in baseflow. Our findings represent a starting point to understand the impact of groundwater withdrawal over the SFB.

\section{Materials and Methods}

\subsection{Study area description}

Our study area, the SFB, is challenged by water conflicts for multiple uses, with irrigation for food production representing the largest. The SFB is located in northeast Brazil and covers 639,000 $\mathrm{km}^{2}$ over seven Brazilian States: Bahia (contains $48.2 \%$ of the SFB), Minas Gerais (36.8\%), Pernambuco $(10.9 \%)$, Alagoas (2.2\%), Sergipe (1.2\%), Goias (0.5\%) and Federal District (0.2\%) (Figure 1). The SFR has a length of 2,600 km from its headwaters (northern Minas Gerais State) to estuary (between Alagoas and Sergipe States) in the Atlantic Ocean. The annual average flow and the 95th percentile flow (i.e., $Q_{95}-$ a metric of low flows) of SFR is 2,914 $\mathrm{m}^{3} \mathrm{~s}^{-1}$ and $875 \mathrm{~m}^{3} \mathrm{~s}^{-1}$, respectively [32].

Irrigated agriculture is the most important economic activity in the SFB and is responsible for $86 \%$ of permitted surface water withdrawals [33]. However, the SFR also supplies water for $\sim 16$ million people in 521 municipalities [34] and has hydroelectric power plants which supply $\sim 12 \%$ $(10,708 \mathrm{MW})$ of the installed generation capacity in the Brazil [35]. The SFB accounts for $23 \%\left(\sim 750 \mathrm{~m}^{3}\right.$ $\mathrm{s}^{-1}$ ) of all the surface water abstractions permits in Brazil [33]. 


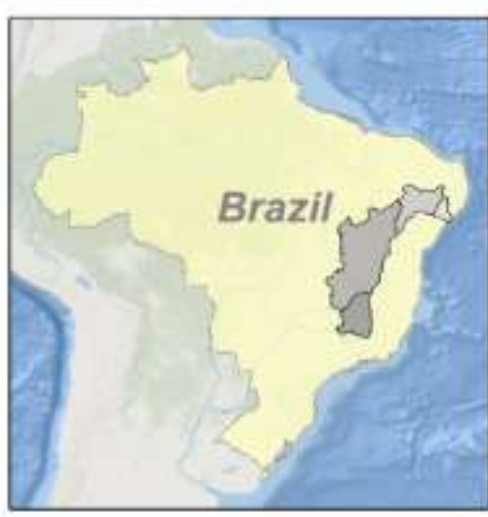

- Streamflow gauges

- Hydrography

Semi-arid

Brazilian states

Lower SFB

$\square$ Sub-middle SFB

- Middle SFB

Upper SFB

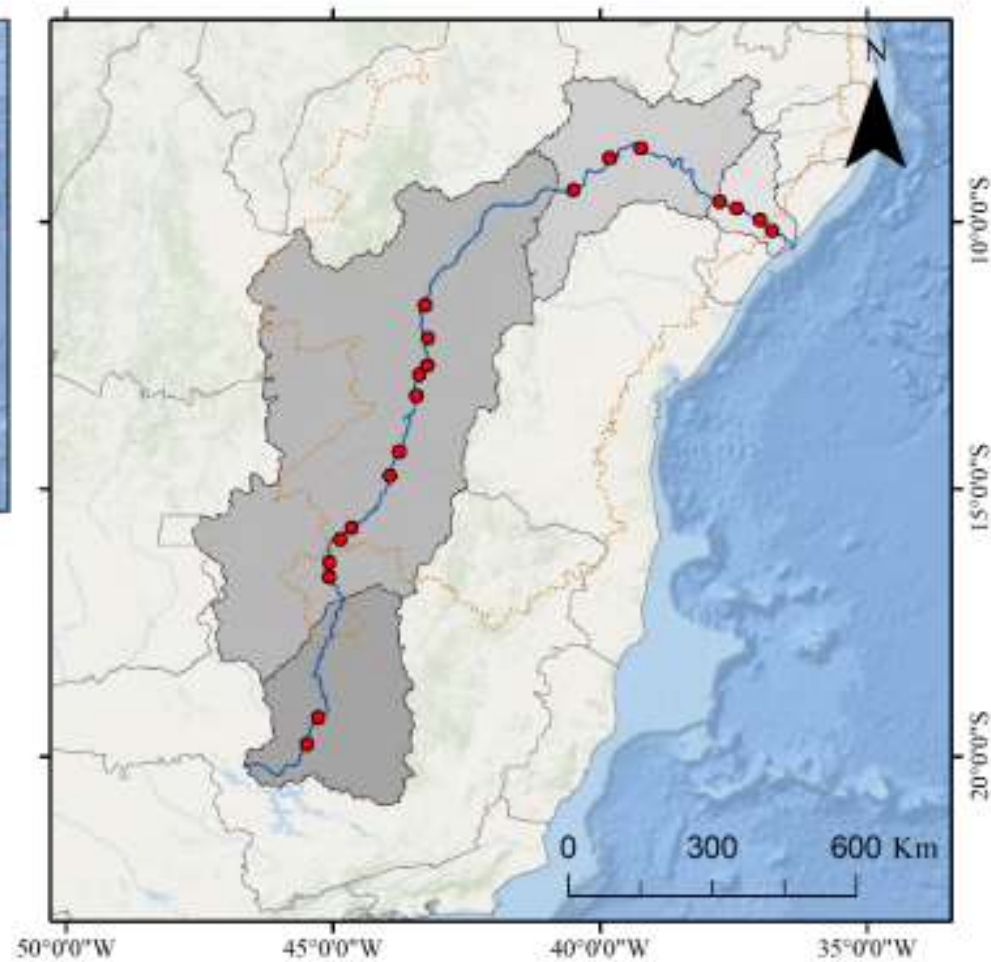

Figure 1. The Sao Francisco River Basin (SFB) location and river gauges along the Sao Francisco River (SFR).

Although the average precipitation is $938 \mathrm{~mm} \mathrm{y}^{-1}$ over the entire SFB [32], there is large variation in precipitation within the SFB (Error! Reference source not found.). Due to its variability in precipitation regimes and biomes, the SFB is divided into four hydrographical regions: Upper, Middle, Sub-middle, and Lower (Figure 1). The main characteristics (e.g., precipitation, climate classification and biome) of each hydrographical region are summarized in Error! Reference source not found.. The entire Sub-middle SFB, and most of the Lower and Middle SFB, are in the Brazilian Semiarid climate zone (Figure 1), which is considered the driest region in the country due to prolonged droughts. The spatial distribution of precipitation, evapotranspiration and climate type are shown in Figure 2.

Table 1. The main features of hydrographical regions of the Sao Francisco River Basin (SFB).

\begin{tabular}{|c|c|c|c|c|c|}
\hline $\begin{array}{c}\text { Main } \\
\text { features }\end{array}$ & $\begin{array}{l}\text { Upper } \\
\text { SFB }\end{array}$ & $\begin{array}{c}\text { Middle } \\
\text { SFB }\end{array}$ & $\begin{array}{c}\text { Sub-middle } \\
\text { SFB }\end{array}$ & $\begin{array}{c}\text { Lower } \\
\text { SFB }\end{array}$ & Reference \\
\hline Area $\left(\mathrm{km}^{2}\right)$ & 100,085 & 402,491 & 110,473 & 25,417 & [36] \\
\hline Population (million) & 7.1 & 3.4 & 2.3 & 1.4 & [37] \\
\hline Mean precipitation $\left(\mathrm{mm} \mathrm{y}^{-1}\right)$ & 1,395 & 918 & 526 & 749 & This study \\
\hline $\begin{array}{l}\text { Mean evapotranspiration } \\
\qquad\left(\mathrm{mm} \mathrm{y}^{-1}\right)\end{array}$ & 914 & 762 & 480 & 673 & This study \\
\hline Biome & ${ }^{1}$ Cerrado & $\begin{array}{l}{ }^{1} \text { Cerrado } \\
\text { (west) and } \\
{ }^{2} \text { Caatinga } \\
\text { (east) }\end{array}$ & ${ }^{2}$ Caatinga & $\begin{array}{l}{ }^{2} \text { Caatinga and } \\
\text { Atlantic rainforest }\end{array}$ & [38] \\
\hline Climate & $\begin{array}{l}{ }^{3} \text { Aw (hot and } \\
\text { humid with } \\
\text { wet summer) }\end{array}$ & $\begin{array}{l}{ }^{3} \mathrm{Aw} \text { and } \\
\text { BShw } \\
\text { (semiarid) }\end{array}$ & ${ }^{3} \mathrm{BSh}$ & $\begin{array}{l}{ }^{3} \text { As (hot and humid } \\
\text { with wet winter) and } \\
\text { 3BSh (semiarid with } \\
\text { short wet season) }\end{array}$ & [39] \\
\hline
\end{tabular}

${ }^{1}$ Cerrado is a Brazilian (tropical) savanna. ${ }^{2}$ Caatinga is a Brazilian herbaceous and arborescent vegetation in the semiarid region. ${ }^{3}$ According to Köppen's climate classification. 


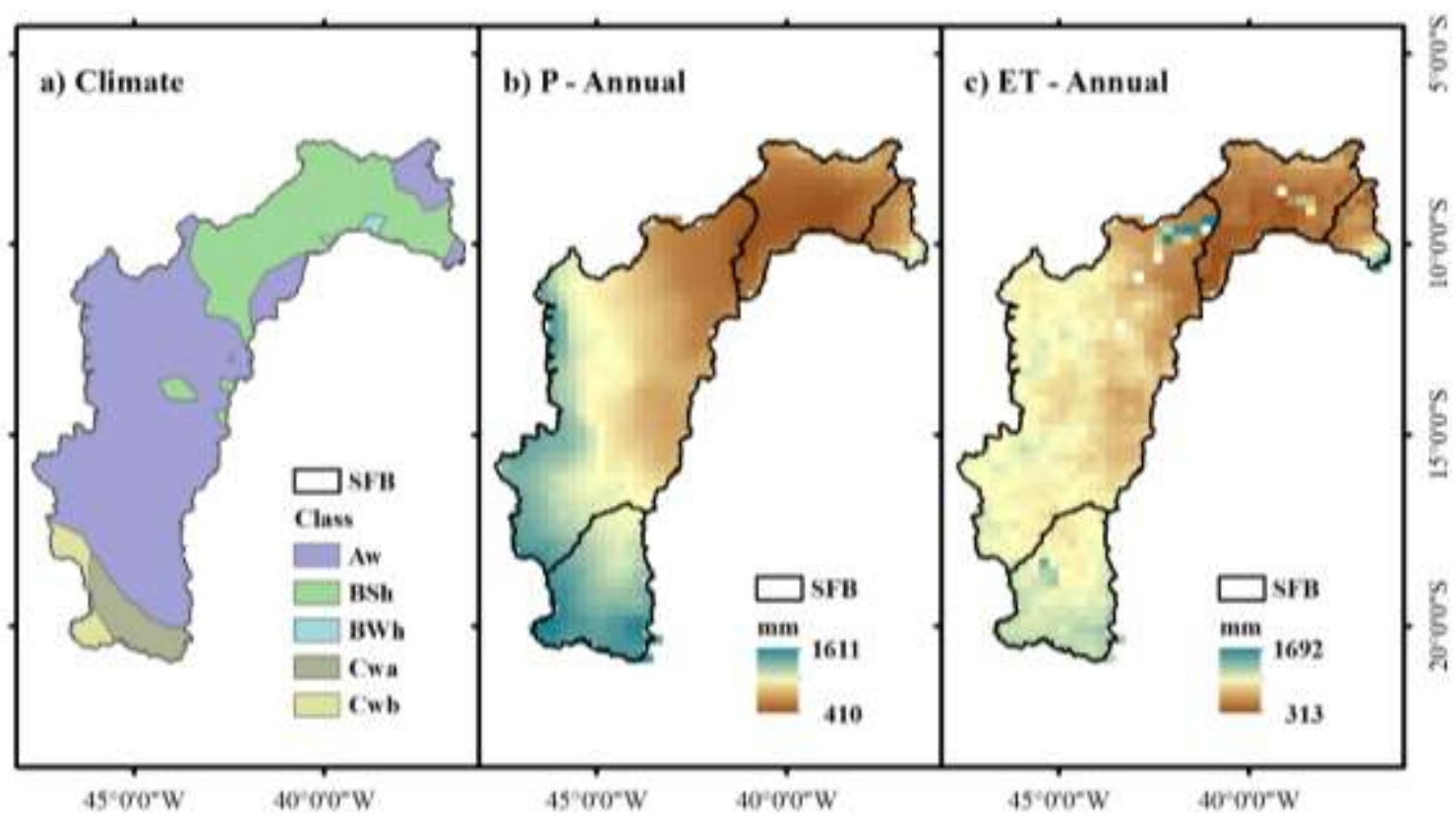

Figure 2. The spatial distribution of: (a) climate type according to Köppen's classification; (b) annual mean precipitation (P); and (c) annual mean evapotranspiration (ET) over the Sao Francisco Basin (SFB).

\subsection{Data sources}

\subsubsection{Streamflow data}

We obtained daily streamflow records from 20 river gauges located in the SFR over the 19802015 period, which we averaged to annual mean flow. The streamflow data were downloaded from the Brazilian Water Agency (ANA, Agencia Nacional de Aguas) website (http://www.snirh.gov.br/hidroweb/). The river gauges span the four hydrological regions as following: two gauges in the Upper SFB (40070000 and 40100000), 11 gauges in the Middle SFB (42210000, 43200000, 44200000, 44290000, 44500000, 45298000, 45480000, 46035000, 46105000, 46150000 and 46360000), three gauges in the Sub-middle SFB (48020000, 48290000 and 48590000) and four gauges in the Lower SFB (49330000, 49370000, 49660000 and 49705000).

\subsubsection{Precipitation, evapotranspiration and water storage change data}

To evaluate potential drivers of streamflow changes in the SFB, we computed spatiotemporal trends in water fluxes (precipitation, P, evapotranspiration, ET, and total water storage, TWS). We used a ground-based gridded rainfall to retrieve daily P data (from 1980 to 2015) with $0.25^{\circ} \times 0.25^{\circ}$ spatial resolution [40]. The gridded $\mathrm{P}$ data were obtained by interpolation technique using data from $\sim 4,000$ rain gauges over the Brazil [i.e., 40] and have been widely used in regional studies [41-44].

Daily ET and potential ET (PET) was acquired from the Global Land Evaporation Amsterdam Model (GLEAM) dataset [45], with $0.25^{\circ} \times 0.25^{\circ}$ spatial resolution during the $1980-2015$ period, which is available at https:/www.gleam.eu/. GLEAM is dedicated to the estimation of terrestrial evaporation and root-zone soil moisture from satellite data [46]. Basically, GLEAM separately derives the different components of terrestrial evaporation, i.e. transpiration (from short and tall vegetation), bare soil evaporation, open-water evaporation, interception loss, and sublimation on daily basis [45]. GLEAM has been used to evaluate trends in ET at global scale [47].

Additionally, we analyzed monthly TWS anomaly with $1^{\circ} \times 1^{\circ}$ spatial resolution (from mid-2002 to 2015) measured by the Gravity Recovery and Climate Experiment (GRACE) satellite mission. GRACE measures temporal variations in the Earth's gravity field, which can be used to estimate changes in TWS (i.e., surface water, snow, groundwater and soil moisture storage) [48]. GRACE- 
based monthly gravity products are officially processed and distributed by three processing centers: GeoforschungsZentrum Potsdam (GFZ), Jet Propulsion Laboratory (JPL) and Center for Space Research of the University of Texas at Austin (CSR). Traditionally, two approaches have been used to generate GRACE-based TWS solutions: spherical harmonics and mass concentration blocks (mascons) [49]. Here, we used JPL Release 06 (RL06) mascons solution, which is available at https://grace.jpl.nasa.gov/data/get-data/jpl_global_mascons/.

Trends in P, ET, and TWS dataset were analyzed on annual and seasonal basis. Seasons were defined as: DJF (December, January and February), MAM (March, April and May), JJA (June, July and August) and SON (September, October and November). We used the location of groundwater wells and information about irrigation withdrawals from the Brazilian Geological Survey (CPRM). Further, we acquired land use and land cover information over the SFB from MapBiomas Brazil Project. MapBiomas is a collaborative multi-institutional initiative to generate annual land cover and use maps in $30 \mathrm{~m}$ resolution using automatic classification processes applied to satellite images [50]. The complete description of the MapBiomas Brazil Project and dataset can be accessed at http://mapbiomas.org.

\subsection{Partitioning of streamflow into baseflow and quickflow}

We quantified trends in total streamflow $\left(\mathrm{Q}_{\mathrm{t}}\right)$, baseflow $\left(\mathrm{Q}_{\mathrm{b}}\right)$, representing slowly varying inputs to streamflow such as groundwater), and quickflow $\left(Q_{q}\right)$, representing quickly varying inputs to streamflow such as surface runoff). The baseflow regime was taken as representative of the overall behavior of groundwater contribution over the SFB. Digital filters have been widely used to estimate the contribution of groundwater to streamflow [42,51] and have been shown suitable in comparison to other approaches over large spatial scales [52-54]. We applied two digital filters to decompose $Q_{t}$ into $\mathrm{Q}_{b}$ and $\mathrm{Q}_{q}$ components at daily resolution, and used the average value of $\mathrm{Q}_{b}$ of the two filters. The $\mathrm{Q}_{t}, \mathrm{Q}_{\mathrm{b}}$ and $\mathrm{Q}_{\mathrm{q}}$ at daily resolution was then aggregated at the annual timescale.

First, the one-parameter recursive digital filter [55] was applied to estimate $Q_{b}$ on daily time step (i) as follows:

$$
\begin{aligned}
& Q_{q_{i}}=\epsilon Q_{q_{i-1}}+\frac{1-\epsilon}{2}\left(Q_{t_{i}}-Q_{t_{i-1}}\right) \\
& Q_{b_{i}}=Q_{t_{i}}-Q_{q_{i}}
\end{aligned}
$$

where $\epsilon$ is the filter parameter which should assume a single value of 0.925 to generate realistic comparison to manual decomposition techniques [51,56].

We also applied a second, two-parameter digital filter by Eckhardt [57] at a daily time step given by:

$$
\mathrm{Q}_{\mathrm{b}_{\mathrm{i}}}=\frac{\left(1-\mathrm{BFI}_{\max }\right) \mathrm{aQ}_{\mathrm{b}_{\mathrm{i}}-1}+(1-\mathrm{a}) \mathrm{BFI}_{\max } \mathrm{Q}_{\mathrm{t}_{\mathrm{i}}}}{1-\mathrm{aBFI} \max }
$$

where $\mathrm{BFI}_{\max }$ is the maximum value of the baseflow index (Eq. 4) that can be modelled by Eq. (3) and $\mathrm{a}$ is a constant (see Eckhardt, 2008). Following Eckhardt [57], we adopted $\mathrm{BFI}_{\max }=0.80$ and a $=0.98$ (i.e., perennial streams with porous aquifers). These values are specifically suitable for some important (granular) porous hydrogeological units presented in the SBF, for example, the Urucuia Group, which represents an important source of groundwater contribution to SFR flow [59].

To evaluate the role of groundwater contribution to SFR, we chose baseflow index (BFI) as hydrological signature. The BFI represents how extensive groundwater contribution is to streamflow [60]. It was calculated as a long-term ratio between $Q_{b}$ and $Q_{t}$ (Eq. 4) at daily time step. 


$$
\mathrm{BFI}=\frac{\sum_{\mathrm{i}=1}^{\mathrm{N}} \mathrm{Q}_{\mathrm{b}_{\mathrm{i}}}}{\sum_{\mathrm{i}=1}^{\mathrm{N}} \mathrm{Q}_{\mathrm{t}_{\mathrm{i}}}}
$$

The BFI was calculated for each gauge. High BFI values $(>0.70)$ indicate that groundwater is the major contributor on streamflow [61]. Conversely, low BFI values $(\mathrm{BFI}<0.40)$ indicate that quickflow is predominant in terms of streamflow, attesting greater surface runoff [61].

\section{Results}

\subsection{Streamflow and baseflow spatial variation}

Error! Reference source not found. shows the distribution of annual streamflow and baseflow for river gauges over the SFB. The median $Q_{t}\left(\bar{Q}_{t}\right)$ and the upper and lower bounds of the interquartile range (IQR) of $Q_{t}\left(25^{\text {th }} \leq \mathrm{IQR} \leq 75^{\text {th }}\right.$ percentile) increased moving downstream from the Upper SFB $\left(\overline{\mathrm{Q}}_{\mathrm{t}}=195 \mathrm{~m}^{3} \mathrm{~s}^{-1} ; 154 \leq \mathrm{IQR} \leq 241 \mathrm{~m}^{3} \mathrm{~s}^{-1}\right)$, to the Middle SFB $\left(\overline{\mathrm{Q}}_{\mathrm{t}}=1,907 \mathrm{~m}^{3} \mathrm{~s}^{-1} ; 1,505 \leq \mathrm{IQR} \leq\right.$ 2,378 $\left.\mathrm{m}^{3} \mathrm{~s}^{-1}\right)$, to the Sub-middle SFB $\left(\overline{\mathrm{Q}}_{\mathrm{t}}=1,997 \mathrm{~m}^{3} \mathrm{~s}^{-1} ; 1,745 \leq \mathrm{IQR} \leq 2,485 \mathrm{~m}^{3} \mathrm{~s}^{-1}\right)$ (Error! Reference source not found.). On the other hand, we observed a slight decreasing in both the $25^{\text {th }}$ percentile of $\mathrm{Q}_{\mathrm{t}}$ and $\overline{\mathrm{Q}}_{\mathrm{t}}$ from the Sub-middle to the Lower SFB $\left(\overline{\mathrm{Q}}_{\mathrm{t}}=1,920 \mathrm{~m}^{3} \mathrm{~s}^{-1} ; 1,677 \leq \mathrm{IQR} \leq 2,535 \mathrm{~m}^{3} \mathrm{~s}^{-1}\right)$.

Similarly, the median $\mathrm{Q}_{\mathrm{b}}$ within each hydrographical region $\left(\overline{\mathrm{Q}}_{\mathrm{b}}\right)$ followed the behavior of $\overline{\mathrm{Q}}_{\mathrm{t}}$. That is, $\overline{\mathrm{Q}}_{\mathrm{b}}$ increased from the Upper SFB $\left(\overline{\mathrm{Q}}_{\mathrm{b}}=161 \mathrm{~m}^{3} \mathrm{~s}^{-1} ; 125 \leq \mathrm{IQR} \leq 198 \mathrm{~m}^{3} \mathrm{~s}^{-1}\right)$ to the Middle $\operatorname{SFB}\left(\overline{\mathrm{Q}}_{\mathrm{b}}=1,588 \mathrm{~m}^{3} \mathrm{~s}^{-1} ; 1,232 \leq \mathrm{IQR} \leq 1,996 \mathrm{~m}^{3} \mathrm{~s}^{-1}\right)$ to the Sub-middle SFB $\left(\overline{\mathrm{Q}}_{\mathrm{b}}=1,669 \mathrm{~m}^{3} \mathrm{~s}^{-1} ; 1,465 \leq\right.$ $\mathrm{IQR} \leq 2,115 \mathrm{~m}^{3} \mathrm{~s}^{-1}$ ) (Error! Reference source not found.). However, it is interesting that the increased $\overline{\mathrm{Q}}_{\mathrm{b}}$ from the Middle to the Sub-middle SFB was quite small. Further, we found a slight decreased regime in both $\overline{\mathrm{Q}}_{\mathrm{b}}$ and the $25^{\text {th }}$ percentile of $\mathrm{Q}_{\mathrm{b}}$ from the Sub-middle to the Lower $\mathrm{SFB}\left(\overline{\mathrm{Q}}_{\mathrm{b}}=1,638\right.$ $\left.\mathrm{m}^{3} \mathrm{~s}^{-1} ; 1,420 \leq \mathrm{IQR} \leq 2,168 \mathrm{~m}^{3} \mathrm{~s}^{-1}\right)$.

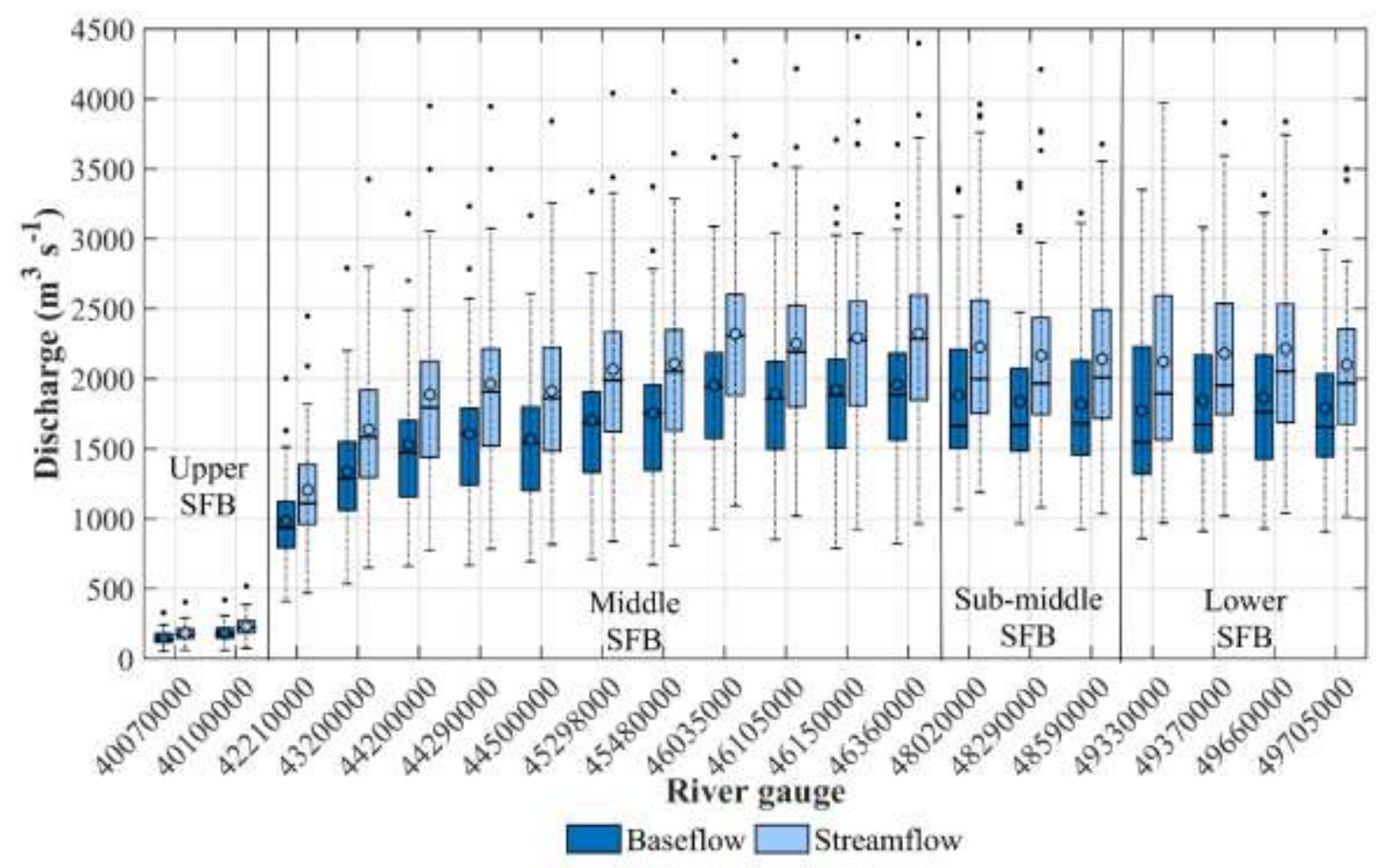

Figure 3. Boxplot of baseflow and streamflow of Sao Francisco River in the hydrographical regions (Upper, Middle, Sub-middle and Lower SFB) over the 1980-2015 period. 
Baseflow, representing slowly varying water sources such as groundwater contributions, accounts for the large majority of $Q_{t}$ in all hydrographical regions of the SFB. BFI for all gauges exceeded 0.80, with relatively little difference in BFI among gauges (Error! Reference source not found.). The highest and lowest value of BFI were observed in the Sub-middle and the Upper SFB, respectively (Error! Reference source not found.). In general, the BFI tended to increase from the Upper to Lower SFB.

Table 2. The annual trend magnitude for streamflow $\left(Q_{t}\right)$, baseflow $\left(Q_{b}\right)$ and quickflow $\left(Q_{q}\right)$ in the Sao Francisco Basin (SFB) according to river gauge. Trends were assessed using the Mann-Kendall and Theil-Sen's slope estimator at 0.05 of significant level.

\begin{tabular}{|c|c|c|c|c|c|c|c|c|}
\hline \multirow{2}{*}{$\begin{array}{l}\text { Rain gauge } \\
\text { number }\end{array}$} & \multirow{2}{*}{$\begin{array}{c}\text { Hydrographical } \\
\text { Region }\end{array}$} & \multirow[t]{2}{*}{ BFI } & \multicolumn{3}{|c|}{ Trends } & \multicolumn{3}{|c|}{$\begin{array}{c}\text { Trend magnitude } \\
\left(\mathrm{m}^{3} \mathrm{~s}^{-1} \mathrm{y}^{-1}\right)\end{array}$} \\
\hline & & & $\mathbf{Q}_{t}$ & $\mathbf{Q}_{b}$ & $\mathbf{Q q}_{\mathbf{q}}$ & $\mathbf{Q}_{\mathrm{t}}$ & $\mathbf{Q}_{b}$ & $\mathbf{Q}_{q}$ \\
\hline 40070000 & Upper & 0.81 & - & - & - & -0.94 & -0.83 & -0.15 \\
\hline 40100000 & SFB & 0.80 & - & - & - & -1.79 & -1.47 & -0.32 \\
\hline 42210000 & \multirow{11}{*}{$\begin{array}{l}\text { Middle } \\
\text { SFB }\end{array}$} & 0.82 & & & & -15.21 & -11.91 & -3.19 \\
\hline 43200000 & & 0.81 & & & & -19.41 & -17.82 & -4.00 \\
\hline 44200000 & & 0.81 & & & 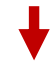 & -27.70 & -21.13 & -5.47 \\
\hline 44290002 & & 0.82 & & & & -29.18 & -23.43 & -4.73 \\
\hline 44500000 & & 0.82 & & & & -25.92 & -20.75 & -4.53 \\
\hline 45298000 & & 0.83 & & & $\nabla$ & -30.49 & -25.70 & -4.86 \\
\hline 45480000 & & 0.83 & & & & -35.29 & -29.68 & -5.12 \\
\hline 46035000 & & 0.84 & & & & -33.63 & -28.02 & -4.92 \\
\hline 46105000 & & 0.84 & & & & -35.08 & -30.63 & -4.87 \\
\hline 46150000 & & 0.84 & & r & & -36.18 & -30.18 & -5.69 \\
\hline 46360000 & & 0.84 & & $\downarrow$ & $V$ & -36.79 & -30.50 & -5.56 \\
\hline 48020000 & \multirow{3}{*}{$\begin{array}{l}\text { Sub-middle } \\
\text { SFB }\end{array}$} & 0.85 & & & & -33.81 & -26.27 & -6.55 \\
\hline 48290000 & & 0.85 & & & 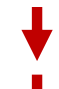 & -31.95 & -23.89 & -6.20 \\
\hline 48590000 & & 0.85 & & & 1 & -33.61 & -28.34 & -5.71 \\
\hline 49330000 & \multirow{4}{*}{$\begin{array}{l}\text { Lower } \\
\text { SFB }\end{array}$} & 0.83 & & & & -38.69 & -32.78 & -6.12 \\
\hline 49370000 & & 0.85 & & & & -36.48 & -28.51 & -7.23 \\
\hline 49660000 & & 0.84 & $\downarrow$ & $\mathbf{1}$ & $\boldsymbol{\perp}$ & -31.16 & -25.95 & -6.05 \\
\hline 49705000 & & 0.85 & $\mathbf{I}$ & $\downarrow$ & l & -29.12 & -23.71 & -5.65 \\
\hline
\end{tabular}

The red arrow represents significant decreasing trend. BFI = baseflow index. - means nonsignificant trend.

\subsection{Trends in streamflow, baseflow and quickflow}

In general, we found a significant decreasing trend in $Q_{t}, Q_{b}$, and $Q_{q}$ (at $\alpha=0.05$ ) over the SFB during 1980-2015 (Error! Reference source not found.). Trends in the two gauges located in the Upper SFB were not significant, while all other gauges had significant decreasing trends for all components of flow. Averaged over all gauges, $Q_{b}$ in the SFB is decreasing at a rate of $-26.12 \mathrm{~m}^{3} \mathrm{~s}^{-1}$ $\mathrm{y}^{-1}(1980-2015)$. The trend magnitude in $\mathrm{Q}_{\mathrm{b}}$ varied from -11.91 to $-30.63 \mathrm{~m}^{3} \mathrm{~s}^{-1} \mathrm{y}^{-1}$ over the Middle SFB, from -23.89 to $-26.27 \mathrm{~m}^{3} \mathrm{~s}^{-1} \mathrm{y}^{-1}$ over the Sub-middle SFB and from -32.78 to $23.71 \mathrm{~m}^{3} \mathrm{~s}^{-1} \mathrm{y}^{-1}$ over the Lower SFB (Error! Reference source not found.). Moving from the SFB to the outlet, trend magnitude 
became significantly more negative. Overall, the trends observed in $\mathrm{Q}_{\mathrm{b}}$ explain the large majority $(82 \%)$ of the observed trends in $Q_{t}$, indicating that observed decreases in streamflow can be primarily be attributed to changing baseflow conditions.

Similar to trends in $Q_{t}$ and $Q_{b}$, significant decreases in $Q_{q}$ were found throughout the SFB (Error! Reference source not found.). Trend magnitude in $Q_{q}$ ranged from -3.19 to $-5.69 \mathrm{~m}^{3} \mathrm{~s}^{-1} \mathrm{y}^{-1}$ in the Middle, from -5.71 to $6.55 \mathrm{~m}^{3} \mathrm{~s}^{-1} \mathrm{y}^{-1}$ in the Sub-middle, and between -5.65 and $-7.23 \mathrm{~m}^{3} \mathrm{~s}^{-1} \mathrm{y}^{-1}$ in the Lower SFB. Overall, trend magnitude in $\mathrm{Q}_{\mathrm{q}}$ became more negative from the Middle to Sub-middle and Lower SFB. Our spatial analysis approach did not explain the significant decreases in $Q_{q}$.

\subsection{Trends in precipitation, evapotranspiration and water storage changes}

The annual P and ET were not significant (at $\alpha=0.05$ ) over most of the SFB during 1980-2015 (Figure 3c,d). Nevertheless, a significant decreasing trend in annual $P$ was observed in few regions over the western Middle SFB, specifically next to the western edge of the basin (Figure 3c) which is a region with widespread irrigation (Figure 3b). In addition, annual ET tended to decrease in few regions over central and western part of the Middle SFB and in the Upper SFB (Figure 3d). We also noted a significant negative trend in TWS over almost the SFB, mainly over Middle SFB (Figure 3e). On the other hand, a nonsignificant trend in TWS was noted in the Lower SFB (Figure 3e).
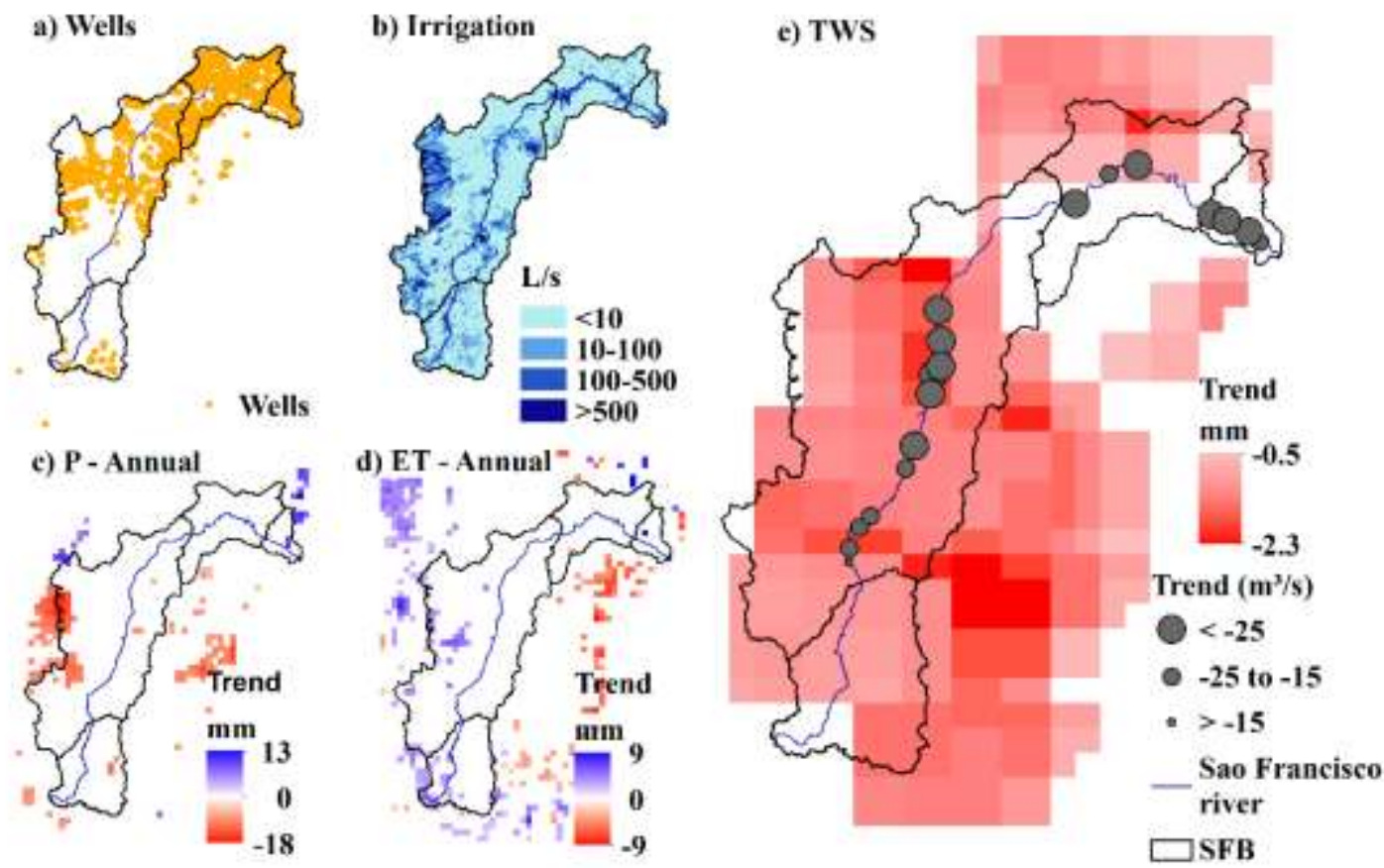

Figure 3. (a) Location of the wells. (b) Irrigation demand over the Sao Francisco River. Trend magnitude in the annual: (c) precipitation $(P),($ d) evapotranspiration $(E T)$, and (e) terrestrial water storage change $(T W S)$ and baseflow. Trends in baseflow along the Sao Francisco River is indicated by the grey circles. Trends were assessed using the Mann-Kendall and Theil-Sen's slope estimator at 0.05 of significant level. White color means nonsignificant trend.

One should note the overlap between regions with decreasing P and TWS, decreasing $Q_{b}$, and increasing ET in the Middle SFB, which has most irrigated agriculture in the region (Figure 3b-e). A strong trend magnitude in TWS of $-2.3 \mathrm{~mm} \mathrm{y}^{-1}$ occurred in the Middle SFB around the SFR channel path near regions with large irrigation withdrawals (Figure 3b,e). Furthermore, we noted some regions with a significant decreasing trend in TWS $\left(-1.4 \leq\right.$ TWS $\leq-0.5 \mathrm{~mm} \mathrm{y}^{-1}$; Figure 3e) over the Sub-middle SFB, which has a large number of irrigation wells (Figure 3a). However, information about the water demand and purpose of individual wells (e.g., irrigation and urban supply system) 
were not available. Moreover, although these wells are documented we cannot identify which ones were in operation.

The seasonal analysis revealed an overall nonsignificant trend in $\mathrm{P}$ over the SFB (Error! Reference source not found.a-d). The exception is a strong decreasing in $\mathrm{P}\left(-12 \leq \mathrm{P} \leq-1.0 \mathrm{~mm} \mathrm{y}^{-1}\right)$ over the western Middle SFB during DJF season (Error! Reference source not found.a). In addition, the $\mathrm{P}$ also tended to increase $\left(\mathrm{P}=9 \mathrm{~mm} \mathrm{y}^{-1}\right)$ strongly in a few regions over and adjacent to the Lower SFB during JJA season (Error! Reference source not found.c). Thus, in general, the seasonal P results indicate that the decreases in annual $\mathrm{P}$ are primarily driven by reductions in summer (DJF) precipitation.
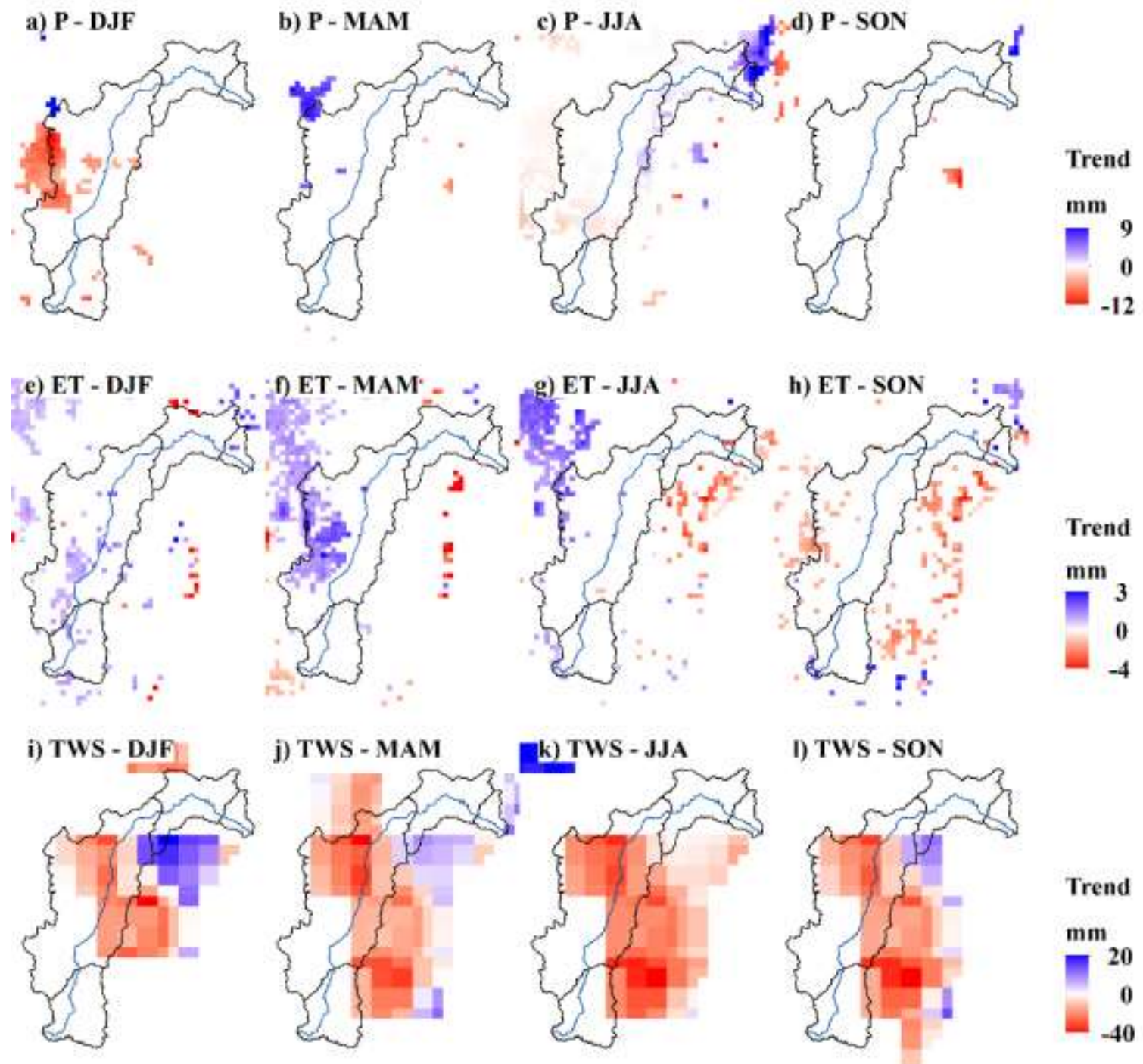

Figure 5. Trend magnitude in the seasonal: (a-d) precipitation $(P),(\mathbf{e}-\mathbf{h})$ evapotranspiration $(E T)$, and $(\mathbf{i}-\mathbf{j})$ terrestrial water storage change $(T W S)$ and their magnitudes over the Sao Francisco Basin. DJF = December, January and February; MAM = March, April and May; JJA = June, July and August; and SON $=$ September, October and November. Trends were assessed using the Mann-Kendall and TheilSen's slope estimator at 0.05 of significant level. White color means nonsignificant trend.

We found a remarkable increasing trend in seasonal ET $\left(3.0 \leq \mathrm{ET} \leq 0.5 \mathrm{~mm} \mathrm{y}^{-1}\right)$ specifically in the heavily-irrigated west and central parts of the Middle SFB in the MAM season (Error! Reference source not found.f). The seasonal ET tended to increase by up to $1.0 \mathrm{~mm} \mathrm{y}^{-1}$ during DJF (Error! Reference source not found.e). Conversely, results show a slight decreasing trend in ET $(-1 \leq$ ET $\leq$ $-3.0 \mathrm{~mm} \mathrm{y}^{-1}$ ) during SON season over the western Middle SFB. Additionally, in general, nonsignificant trend in seasonal ET was observed in the Upper, Sub-middle and Lower SFB. 
With regard to TWS, we noted a negative trend in the western and eastern Middle SFB during all seasons (Error! Reference source not found.i-l) where there are large irrigation demand and wells (Figure $3 \mathrm{a}, \mathrm{b})$. For instance, the strongest seasonal decreasing trend $\left(-40 \leq\right.$ TWS $\left.\leq-20 \mathrm{~mm}^{-1}\right)$ overlapped the agricultural irrigation land over the western and central Middle SFB in MAM and JJA (Error! Reference source not found.j,k). Furthermore, TWS significantly increased from JJA to SON and DJF season in the Centre-West and Centre-East of Middle SFB. Conversely, there was a nonsignificant seasonal trend in the Upper, Sub-middle and Lower SFB.

\section{Discussion}

The partitioning of total streamflow into baseflow and quickflow components reveals the major role of groundwater in sustaining the Sao Francisco River discharge. Our results show a strong decreasing trend in baseflow over almost the entire SFB (Error! Reference source not found.), most prominently in the heavily-irrigated Middle SFB, and that baseflow reductions are the primary driver of observed change in total streamflow. The Upper SFB is the only region that presented nonsignificant trends in baseflow during the 1980-2015 period. These results suggest that groundwater withdrawals for irrigation may be the most likely driver responsible for decreased baseflow in the Middle SFB and downstream areas. This is supported by the spatial correspondence between irrigated agricultural land (Figure 3b), a decreasing trend in TWS (Error! Reference source not found.i-1), and a strong increasing trend in ET (Error! Reference source not found.f,g). While there are many irrigation wells in this region (Figure 3a), we do not have data on direct surface water withdrawals from the SFR, which may also contribute to strong decreasing trend in $Q_{b}$ near the irrigated land (Figure 3e).

The close relation between increased ET and decreased P over the irrigated area (i.e., Centre-West part of the Middle SFB, which comprises the MATOPIBA region) can be related to deforestation for agricultural cropping. MATOPIBA is located mainly in the Bahia and Tocantins States with irrigated holdings larger than 5,000 ha and water demand is greater than $100 \mathrm{~L} \mathrm{~s}^{-1}$ [62]. MATOPIBA experienced significant expansion of the irrigated agriculture by center pivots from 13 to 1,548 pivots during 1980-2015 [63]. Hence, given the expansion of agricultural land over the Middle SFB from 1985 to 2015 (Figure 4), these lines of evidence combine to suggest that irrigated agricultural expansion induced an increase in groundwater withdrawals, and consequently the increase trend in ET during DJF and MAM. These withdrawals lead to a net increase in water export to the atmosphere (increased ET), decreasing TWS, and ultimately decreases in baseflow over the Middle SFB. This problem mirrors the challenges of diverse settings such as the United States, India, and China where marked increases in groundwater-fed irrigation in the last few decades have lowered groundwater levels and reduced streamflow [64,65].

The observed decrease in ET during SON season may be explained by the harvesting of different crops, mainly maize (known as "safrinha"), sugarcane and wheat [66]. This raises the possibility that the harvest of crops may trigger a deforestation-induced feedback phenomena in which reduced ET can further reduce P, as has been demonstrated in the Amazon forest [i.e., 66]. This is corroborated by the increased TWS from MAM and JJA to SON and DJF period, indicating more infiltration, and eventually groundwater recharge. These results agreed with those reported by $[62,68]$. Although this area also comprises rain-fed agriculture, irrigation is often required during dry periods. Unfortunately, data are not available on the seasonal distribution of groundwater and surface water withdrawals. 

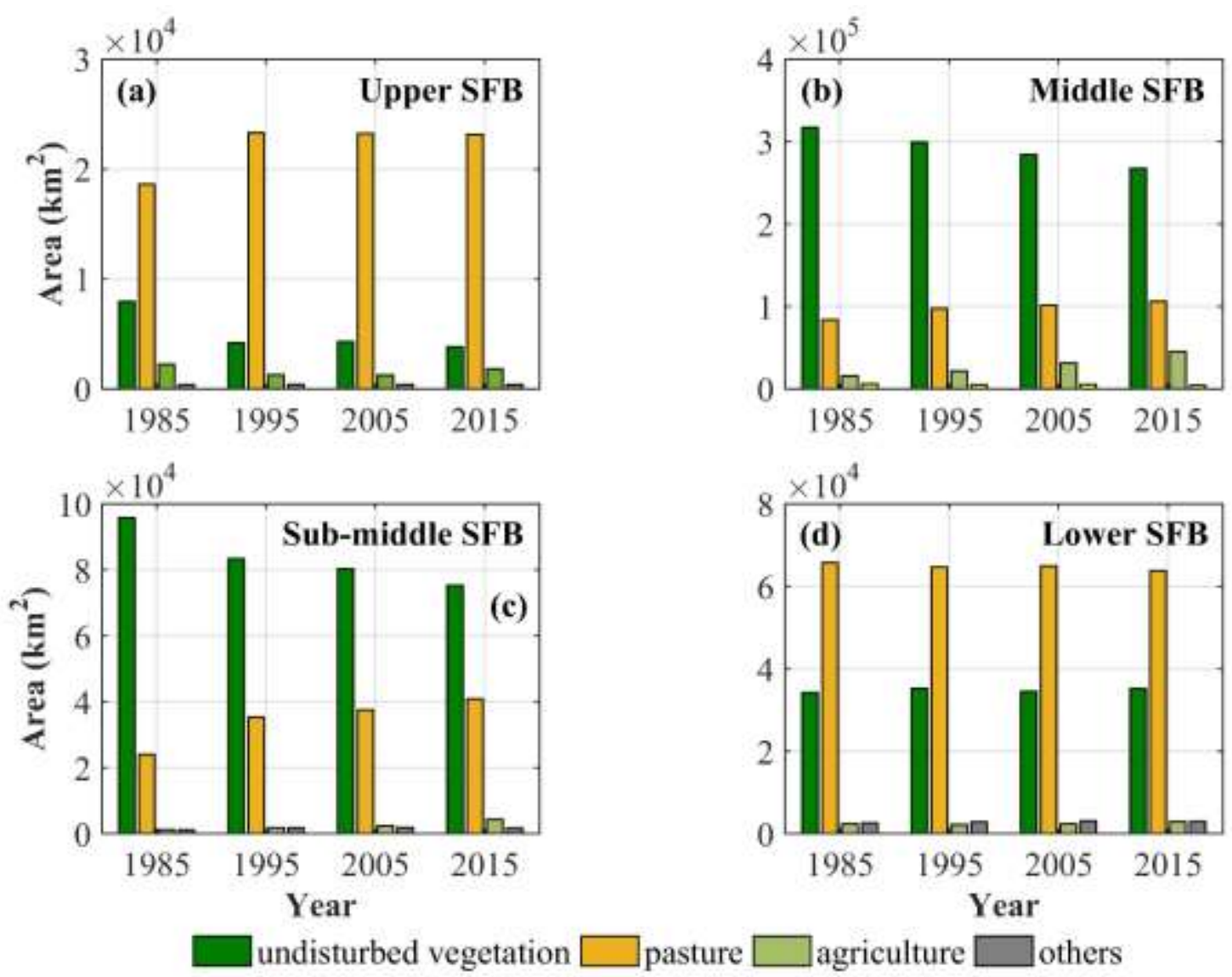

Figure 4. Land use and cover area according to hydrographical regions of the Sao Francisco River Basin (SFB) during 1985-2015: (a) Upper SFB, (b) Middle SFB, (c) Sub-middle SFB, and (d) Lower SFB. Land use classes were acquired from MapBiomas 3.0 (http://mapbiomas.org/).

The decrease in baseflow can be partly related to groundwater irrigation from the Urucuia Aquifer System (UAS). The UAS is an sedimentary aquifer that covers an area of $125,000 \mathrm{~km}^{2}$ and is an important source of water to the SFR, especially during dry seasons [69]. The UAS is located in most part over the western Bahia State by the left bank of SFR and covers the MATOPIBA region. On average, the UAS discharged $792 \mathrm{~m}^{3} \mathrm{~s}^{-1}$ to the SFR in 1980, however this contribution has decreased continuously to $390 \mathrm{~m}^{3} \mathrm{~s}^{-1}$ in 2015 [70]. In addition, previous studies showed that groundwater storage tended to decrease in $-6.5 \pm 2.6 \mathrm{~mm} \mathrm{y}^{-1}\left(9.75 \mathrm{~km}^{3}\right)$ in the UAS over the 2003-2014 period [69]. Therefore, given the importance of the UAS, it is reasonable to infer that groundwater decline in the UAS may have affected the SFR flow, particularly in the Middle SFB, during the 1980-2015 period.

In the Sub-middle SFB, it is likely that baseflow reduction is driven by combined surface and groundwater withdrawals. Annual decreasing trend in TWS occurred only in the Centre-North part of Sub-middle (near the SFR) and was lower related to the Middle SFB. This indicated that the surface water withdrawals for irrigation may be responsible for the lack of TWS trends in the regions south of the SFR in the Sub-middle SFB. The Sub-middle SFB has been subjected to expansion of irrigated agriculture (Figure 4), primarily vineyards and mango orchards in the Juazeiro (Bahia State) and Petrolina city (Pernambuco State) [71]. To carry out the irrigated expansion in this region, the undisturbed vegetation (Caatinga) have been replaced by vineyards [72]. Since mango orchards and vineyards are perennial fruit crops, irrigation from surface and/or groundwater is needed during dry periods. [73] reported the impact of replacing Caatinga to vineyards and mango orchard on ET over 
the Sub-middle SFB. They concluded that ET increased by 2 and 3 times for vineyards (450-800 mm $\left.\mathrm{y}^{-1}\right)$ and mango orchard (500-1,300 $\left.\mathrm{mm} \mathrm{y}^{-1}\right)$, respectively, in comparison with the Caatinga vegetation (200-400 $\left.\mathrm{mm} \mathrm{y}^{-1}\right)$ in 2006 [73]. However, we surprisingly found a nonsignificant trend in ET over the Sub-middle SFB (Figure 3,Error! Reference source not found.). This may occurred due to the longterm (average) relation between ET, potential evapotranspiration (PET) and P. Using the Budyko framework [74], we find that ET is water-limited by the dry climate (i.e., high temperature and solar radiation) over the Sub-middle SFB (Figure 5). As consequence, significant trends in ET were not detected even with the increased ET after replacing Caatinga vegetation by vineyards and mango orchard. Therefore, it is reasonable to infer that the climatic condition (i.e., P $<$ ET $<$ PET) may be another responsible to the decrease trend in TWS in these regions.

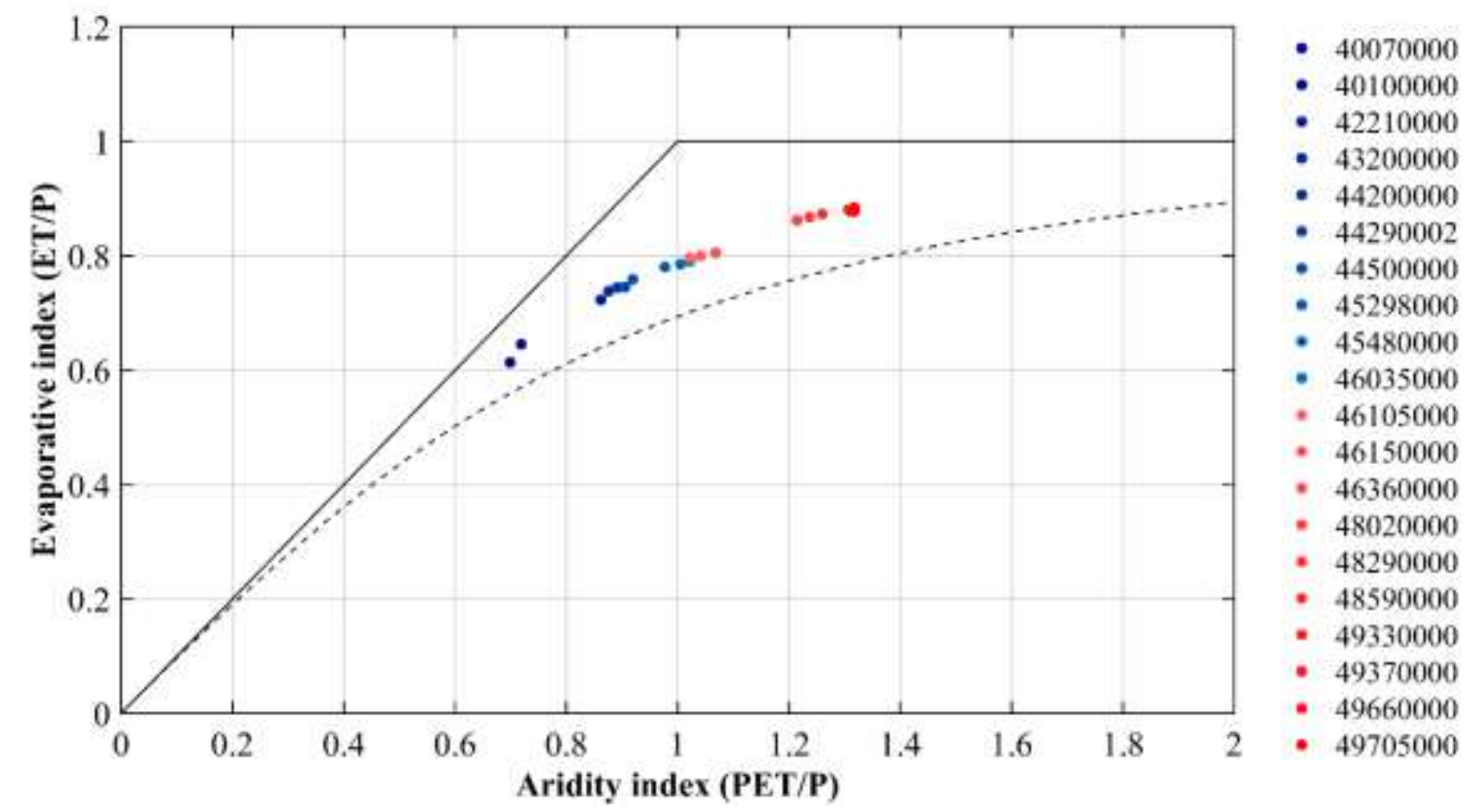

Figure 5. Budyko curve compared to annual streamflow data (colored circles) according to each river gauge over the 1980-2015 period. The dash line is Budyko curve based on the annual values. P, ET and PET are precipitation, evapotranspiration and potential $E T$, respectively. Where $E T$ is computed as streamflow $\left(Q_{t}\right)$ minus precipitation $\left(E T=Q_{t}-P\right)$ and $P E T$ came from the GLEAM data.

However, according to Figure 5 other factors like surface and groundwater withdrawals may explain observed departures from observed streamflow against the Budyko curve. The streamflow depletion we describe above causes ET to be overestimated when calculated as $Q_{t}$ minus $P$ following the Budyko framework, leading to the points shifted upwards above the Budyko curve (Figure 5). Further, climate variability (i.e., P and ET) may overlap the effect of groundwater withdrawals during the study period, making it difficult to evaluate them separately.

\section{Conclusion}

Decreasing streamflow has brought a major concern about water security worldwide, especially in (semi)arid regions. In Brazil, the Sao Francisco Basin (SFB) has experienced water-related problems because of decreased flow in Sao Francisco River (SFR). The SFB is strategically important for national food and energy production with a huge irrigated area, and a population of $~ 16$ million. These multiple water demands make the SFR a socio-economically important region and balancing 
their needs poses a difficult task for decisionmakers. Because the Brazilian government has encouraged the expansion of irrigated agriculture to increase food production, we further expect increased water demand and conflict in the future of the SFB [75].

Although previous studies have focused on the impacts of climate variability on decreasing SFR flow, none has addressed the possible influence of groundwater withdrawals. Here, we provide the first overview of long-term change in relevant hydrological fluxes (i.e., precipitation, evapotranspiration, baseflow and water storage) to constrain potential drivers of the observed decrease in SFR flow. Our findings suggest that significant decreases in SFR flow are primarily due to reduced groundwater contributions to total streamflow (as baseflow) during the 1980-2015 period. While no long-term ground water use data are available for the region, this suggests that groundwater withdrawals may be the most likely driver of the observed negative trend in the SFR baseflow, which is compounded by direct surface water withdrawals. Further investigation is necessary to precisely identify the causes of decreased baseflow and relative importance of different drivers.

Combined, these results indicate that river water and groundwater are hydraulically connected in the SFB, and that groundwater pumping can decrease flow in the SFR. Therefore, we call for increased attention on groundwater management in the SFB, especially in the most heavilyirrigated Middle SFB region. As irrigated agricultural will likely continue to expand and require more water, groundwater will play a key role for future food production.

Author Contributions: Conceptualization, Natalya Kublik, Dulce B. B. Rodrigues and Paulo Tarso Sanches Oliveira; Formal analysis, Murilo Cesar Lucas, Natalya Kublik, Dulce B. B. Rodrigues, Antonio A. Meira Neto, André Almagro, Davi de C. D. Melo, Samuel C. Zipper and Paulo Tarso Sanches Oliveira; Funding acquisition, Paulo Tarso Sanches Oliveira; Investigation, Murilo Cesar Lucas; Methodology, Murilo Cesar Lucas, Natalya Kublik, Dulce B. B. Rodrigues, Antonio A. Meira Neto, André Almagro, Davi de C. D. Melo and Paulo Tarso Sanches Oliveira; Project administration, Dulce B. B. Rodrigues and Paulo Tarso Sanches Oliveira; Supervision, Paulo Tarso Sanches Oliveira; Writing - original draft, Murilo Cesar Lucas; Writing - review \& editing, Dulce B. B. Rodrigues, Antonio A. Meira Neto, André Almagro, Davi de C. D. Melo, Samuel C. Zipper and Paulo Tarso Sanches Oliveira.

Funding: This research was funded by the Ministry of Science, Technology, Innovation and Communication MCTIC and National Council for Scientific and Technological Development - CNPq (grants 441289/2017-7 and 306830/2017-5) and Coordenação de Aperfeiçoamento de Pessoal de Nível Superior - Brasil - CAPES (Finance Code 001 and Capes PrInt).

Conflicts of Interest: The authors declare no conflict of interest.

\section{References}

1. WEF - World Economic Forum The Global Risks Report 2019; 14th ed.; World Economic Forum: Cologny/Geneva Switzerland, 2019; ISBN 978-1-944835-15-6.

2. Cosgrove, W.J.; Loucks, D.P. Water management: Current and future challenges and research directions. Water Resour. Res. 2015, 51, 4823-4839.

3. UN - United Nations The Millennium Development Goals Report; Way, C., Ed.; United Nation: New York, 2015; ISBN 978 - 92-1-101320 -

4. Liu, J.; Yang, H.; Gosling, S.N.; Kummu, M.; Flörke, M.; Pfister, S.; Hanasaki, N.; Wada, Y.; Zhang, X.; Zheng, C.; et al. Water scarcity assessments in the past, present, and future. Earth's Futur. 2017, 5, 545-559.

5. Van Loon, A.F.; Van Lanen, H.A.J. Making the distinction between water scarcity and drought using an observation-modeling framework. Water Resour. Res. 2013, 49, 1483-1502.

6. Kummu, M.; Guillaume, J.H.A.; De Moel, H.; Eisner, S.; Flörke, M.; Porkka, M.; Siebert, S.; Veldkamp, T.I.E.; Ward, P.J. The world's road to water scarcity: Shortage and stress in the 20th century and pathways towards sustainability. Sci. Rep. 2016, 6, 1-16.

7. Wada, Y.; Niko; Ludovicus P H, van B.; Wanders; Bierkens, M.F.P. Human water consumption intensifies hydrological drought worldwide. Environ. Res. Lett. 2013, 8, 34036.

8. Hoekstra, A.Y. Water scarcity challenges to business. Nat. Clim. Chang. 2014, 4, 318-320. 
9. Vörösmarty, C.J.; McIntyre, P.B.; Gessner, M.O.; Dudgeon, D.; Prusevich, A.; Green, P.; Glidden, S.; Bunn, S.E.; Sullivan, C.A.; Liermann, C.R.; et al. Global threats to human water security and river biodiversity. Nature 2010, 467, 555-561.

10. Veldkamp, T.I.E.; Wada, Y.; Aerts, J.C.J.H.; Döll, P.; Gosling, S.N.; Liu, J.; Masaki, Y.; Oki, T.; Ostberg, S.; Pokhrel, Y.; et al. Water scarcity hotspots travel downstream due to human interventions in the 20th and 21st century. Nat. Commun. 2017, 8, 1-12.

11. Döll, P.; Fiedler, K.; Zhang, J. Global-scale analysis of river flow alterations due to water withdrawals and reservoirs. Hydrol. Earth Syst. Sci. 2009, 13, 2413-2432.

12. Arnell, N.W.; Gosling, S.N. The impacts of climate change on river flow regimes at the global scale. J. Hydrol. 2013, 486, 351-364.

13. Döll, P.; Zhang, J. Impact of climate change on freshwater ecosystems: a global-scale analysis of ecologically relevant river flow alterations. Hydrol. Earth Syst. Sci. 2010, 14, 783-799.

14. Flörke, M.; Schneider, C.; McDonald, R.I. Water competition between cities and agriculture driven by climate change and urban growth. Nat. Sustain. 2018, 1, 51-58.

15. Gesualdo, G.C.; Oliveira, P.T.; Rodrigues, D.B.B.; Gupta, H.V. Assessing water security in the S\&amp;amp;\#227;o Paulo metropolitan region under projected climate change. Hydrol. Earth Syst. Sci. 2019, 23, 4955-4968.

16. Gleeson, T.; VanderSteen, J.; Sophocleous, M.A.; Taniguchi, M.; Alley, W.M.; Allen, D.M.; Zhou, Y. Groundwater sustainability strategies. Nat. Geosci. 2010, 3, 378-379.

17. Castle, S.L.; Thomas, B.F.; Reager, J.T.; Rodell, M.; Swenson, S.C.; Famiglietti, J.S. Groundwater depletion during drought threatens future water security of the Colorado River Basin. Geophys. Res. Lett. 2014, 41, 5904-5911.

18. Döll, P.; Müller Schmied, H.; Schuh, C.; Portmann, F.T.; Eicker, A. Global-scale assessment of groundwater depletion and related groundwater abstractions: Combining hydrological modeling with information from well observations and GRACE satellites. Water Resour. Res. 2014, 50, 5698-5720.

19. Famiglietti, J.S. The global groundwater crisis. Nat. Clim. Chang. 2014, 4, 945-948.

20. Gleeson, T.; Wada, Y.; Bierkens, M.F.P.; Van Beek, L.P.H. Water balance of global aquifers revealed by groundwater footprint. Nature 2012, 488, 197-200.

21. Rodell, M.; Famiglietti, J.S.; Wiese, D.N.; Reager, J.T.; Beaudoing, H.K.; Landerer, F.W.; Lo, M.H. Emerging trends in global freshwater availability. Nature 2018, 557, 651-659.

22. Scanlon, B.R.; Faunt, C.C.; Longuevergne, L.; Reedy, R.C.; Alley, W.M.; McGuire, V.L.; McMahon, P.B. Groundwater depletion and sustainability of irrigation in the US High Plains and Central Valley. Proc. Natl. Acad. Sci. U. S. A. 2012, 109, 9320-9325.

23. Voss, K.A.; Famiglietti, J.S.; Lo, M.; de Linage, C.; Rodell, M.; Swenson, S.C. Groundwater depletion in the Middle East from GRACE with implications for transboundary water management in the Tigris-EuphratesWestern Iran region. Water Resour. Res. 2013, 49, 904-914.

24. Richey, A.S.; Thomas, B.F.; Lo, M.; Reager, J.T.; Famiglietti, J.S.; Voss, K.; Swenson, S.; Rodell, M. Quantifying renewable groundwater stress with GRACE. Water Resour. Res. 2015, 51, 5217-5238.

25. Lettenmaier, D.P.; Alsdorf, D.; Dozier, J.; Huffman, G.J.; Pan, M.; Wood, E.F. Inroads of remote sensing into hydrologic science during the WRR era. Water Resour. Res. 2015, 51, 7309-7342.

26. Gleeson, T.; Richter, B. How much groundwater can we pump and protect environmental flows through time? Presumptive standards for conjunctive management of aquifers and rivers. River Res. Appl. 2018, 34, 83-92.

27. Barlow, P.M.; Leake, S.A. Streamflow depletion by wells-Understanding and managing the effects of groundwater pumping on streamflow; Reston, VA, 2012;

28. Zipper, S.C.; Dallemagne, T.; Gleeson, T.; Boerman, T.C.; Hartmann, A. Groundwater Pumping Impacts on Real Stream Networks: Testing the Performance of Simple Management Tools. Water Resour. Res. 2018, 54, 5471-5486.

29. Zipper, S.C.; Gleeson, T.; Kerr, B.; Howard, J.K.; Rohde, M.M.; Carah, J.; Zimmerman, J. Rapid and Accurate Estimates of Streamflow Depletion Caused by Groundwater Pumping Using Analytical Depletion Functions. Water Resour. Res. 2019, 55, 5807-5829.

30. de Graaf, I.E.M.; Gleeson, T.; (Rens) van Beek, L.P.H.; Sutanudjaja, E.H.; Bierkens, M.F.P. Environmental flow limits to global groundwater pumping. Nature 2019, 574, 90-94.

31. OAS/GEF/ANA São Francisco River Basin - Integrated Management of Land Based Activitiesin the São Francisco River Basin; Washington, D.C., 2005;

32. ANA - Agência Nacional de Águas Brazilian Water Resources Report - 2017: Full Report; Brasília, 2018;

33. ANA - Agência Nacional de Águas Conjuntura dos recursos hídricos no Brasil 2019: informe anual; Brasília, 2019; 
34. CODEVASF - Companhia de Desenvolvimento dos Vales dSão Francisco e do Parnaíba Plano nascente São Francisco: : plano de preservação e recuperação de nascentes da bacia do rio São Francisco; Motta, E.J. de O., Gonçalves, N.E.W., Eds.; Editora iABS: Brasília, 2016; ISBN 978-85-64478-39-8.

35. ANA - Agência Nacional de Águas Sala de Situação da Agência Nacional de Águas Available online: https://www.ana.gov.br/sala-de-situacao/sao-francisco/sao-francisco-saiba-mais (accessed on Apr 13, 2020).

36. ANA - Agência Nacional de Águas Conjuntura dos recursos hídricos: informe 2015; Brasília, Brasil, 2015;

37. IBGE - Instituto Brasileiro de Geografia e Estatística Censo demográfico Available online: https://censo2010.ibge.gov.br/ (accessed on Jun 9, 2020).

38. MMA - Ministério do Meio Ambiente Caderno da Região Hidrográfica do São Francisco; Brasília, 2006;

39. CBHSF - Comitê da Bacia Hidrográfica do Rio São Francisco Plano de Recursos Hídricos da Bacia Hidrográfica do Rio São Francisco 2016-2025; Alagoas, 2020;

40. Xavier, A.C.; King, C.W.; Scanlon, B.R. Daily gridded meteorological variables in Brazil (1980-2013). Int. J. Climatol. 2016, 36, 2644-2659.

41. Gadelha, A.N.; Coelho, V.H.R.; Xavier, A.C.; Barbosa, L.R.; Melo, D.C.D.; Xuan, Y.; Huffman, G.J.; Petersen, W.A.; Almeida, C. das N. Grid box-level evaluation of IMERG over Brazil at various space and time scales. Atmos. Res. 2019, 218, 231-244.

42. Gómez, D.; Melo, D.C.D.; Rodrigues, D.B.B.; Xavier, A.C.; Guido, R.C.; Wendland, E. Aquifer Responses to Rainfall through Spectral and Correlation Analysis. JAWRA J. Am. Water Resour. Assoc. 2018, 54, 1341-1354.

43. Melo, D. de C.D.; Scanlon, B.R.; Zhang, Z.; Wendland, E.; Yin, L. Reservoir storage and hydrologic responses to droughts in the Paraná River basin, south-eastern Brazil. Hydrol. Earth Syst. Sci. 2016, 20, 46734688 .

44. Melo, D. de C.D.; Xavier, A.C.; Bianchi, T.; Oliveira, P.T.S.; Scanlon, B.R.; Lucas, M.C.; Wendland, E. Performance evaluation of rainfall estimates by TRMM Multi-satellite Precipitation Analysis 3B42V6 and V7 over Brazil. J. Geophys. Res. Atmos. 2015, 120, 9426-9436.

45. Miralles, D.G.; Holmes, T.R.H.; De Jeu, R.A.M.; Gash, J.H.; Meesters, A.G.C.A.; Dolman, A.J. Global landsurface evaporation estimated from satellite-based observations. Hydrol. Earth Syst. Sci. 2011, 15, 453-469.

46. Martens, B.; Miralles, D.G.; Lievens, H.; van der Schalie, R.; de Jeu, R.A.M.; Fernández-Prieto, D.; Beck, H.E.; Dorigo, W.A.; Verhoest, N.E.C. GLEAM v3: satellite-based land evaporation and root-zone soil moisture. Geosci. Model Dev. 2017, 10, 1903-1925.

47. Miralles, D.G.; Van Den Berg, M.J.; Gash, J.H.; Parinussa, R.M.; De Jeu, R.A.M.; Beck, H.E.; Holmes, T.R.H.; Jiménez, C.; Verhoest, N.E.C.; Dorigo, W.A.; et al. El Niño-La Niña cycle and recent trends in continental evaporation. Nat. Clim. Chang. 2014, 4, 122-126.

48. Rodell, M.; Velicogna, I.; Famiglietti, J.S. Satellite-based estimates of groundwater depletion in India. Nature 2009, 460, 999-1002.

49. Watkins, M.M.; Wiese, D.N.; Yuan, D.-N.; Boening, C.; Landerer, F.W. Improved methods for observing Earth's time variable mass distribution with GRACE using spherical cap mascons. J. Geophys. Res. Solid Earth 2015, 120, 2648-2671.

50. MAPBIOMAS Project MapBiomas - Collection 3.0 of Brazilian Land Cover \& Use Map Series Available online: https://mapbiomas.org/ (accessed on Jun 9, 2020).

51. Nathan, R.J.; McMahon, T.A. Evaluation of automated techniques for base flow and recession analyses. Water Resour. Res. 1990, 26, 1465-1473.

52. Lott, D.A.; Stewart, M.T. Base flow separation: A comparison of analytical and mass balance methods. J. Hydrol. 2016, 535, 525-533.

53. Xie, J.; Liu, X.; Wang, K.; Yang, T.; Liang, K.; Liu, C. Evaluation of typical methods for baseflow separation in the contiguous United States. J. Hydrol. 2020, 583, 124628.

54. Zhang, J.; Zhang, Y.; Song, J.; Cheng, L. Evaluating relative merits of four baseflow separation methods in Eastern Australia. J. Hydrol. 2017, 549.

55. Lyne, L.D.; Hollick, M. Stochastic time-variable rainfall runoff modelling. In Proceedings of the Hydrology and Water Resources Symposium; Institution of Engineers Australia: Perth, Australia, 1979; pp. 89-92.

56. Arnold, J.G.; Allen, P.M.; Muttiah, R.; Bernhardt, G. Automated Base Flow Separation and Recession Analysis Techniques. Ground Water 1995, 33, 1010-1018.

57. Eckhardt, K. How to construct recursive digital filters for baseflow separation. Hydrol. Process. 2005, 19, 507-515.

58. Eckhardt, K. A comparison of baseflow indices, which were calculated with seven different baseflow separation methods. J. Hydrol. 2008, 352, 168-173.

59. Ana - Agência Nacional de Águas Hidrogeologia dos ambientes cársticos da Bacia do Rio São Francisco para a gestão de recursos hídricos: resumo executivo; Brasília, 2018; 
60. Yoshida, T.; Troch, P.A. Coevolution of volcanic catchments in Japan. Hydrol. Earth Syst. Sci. 2016, 20, 11331150.

61. Sawicz, K.; Wagener, T.; Sivapalan, M.; Troch, P.A.; Carrillo, G. Catchment classification: empirical analysis of hydrologic similarity based on catchment function in the eastern USA. Hydrol. Earth Syst. Sci. 2011, 15, 2895-2911.

62. Oliveira, P. T. S. Almagro, A. Colman, C. Kobayashi, A. N. A. Rodrigues, D. B. B. Meira Neto, A. A. Gupta, H. V. Nexus of water-food-energy-ecosystem services in the Brazilian Cerrado. In Water and Climate modeling in large basins 5; Silva, R. C. V. Tucci, C. E. M. Scott, C.A., Ed.; ABRHidro: Porto Alegre, 2019; pp. 7-30.

63. Landau, E.C.; Guimarães, D.P.; Sousa, D.L. de Expansão geográfica da agricultura irrigada por pivôs centrais na Região do Matopiba entre 1985 e 2015; Landau, E.C., Ed.; 1th ed.; Embrapa Milho e Sorgo: Sete Lagoas, 2016; ISBN 1679-0154.

64. Kustu, M.D.; Fan, Y.; Robock, A. Large-scale water cycle perturbation due to irrigation pumping in the US High Plains: A synthesis of observed streamflow changes. J. Hydrol. 2010, 390, 222-244.

65. Scanlon, B.R.; Jolly, I.; Sophocleous, M.; Zhang, L. Global impacts of conversions from natural to agricultural ecosystems on water resources: Quantity versus quality. Water Resour. Res. 2007, 43.

66. CONAB - Companhia Nacional de Abastecimento Acompanhamento da safra brasileira de grãos, v. 2 - Safra 2014/15, n. 10; Companhia Nacional de Abastecimento: Brasília, Brasil, 2015; ISBN 2318-6852.

67. Zemp, D.C.; Schleussner, C.F.; Barbosa, H.M.J.; Hirota, M.; Montade, V.; Sampaio, G.; Staal, A.; WangErlandsson, L.; Rammig, A. Self-amplified Amazon forest loss due to vegetation-atmosphere feedbacks. Nat. Commun. 2017, 8, 1-10.

68. Oliveira, P.T.S.; Nearing, M.A.; Moran, M.S.; Goodrich, D.C.; Wendland, E.; Gupta, H. V. Trends in water balance components across the Brazilian Cerrado. Water Resour. Res. 2014, 50, 7100-7114.

69. Gonçalves, R.D.; Stollberg, R.; Weiss, H.; Chang, H.K. Using GRACE to quantify the depletion of terrestrial water storage in Northeastern Brazil: The Urucuia Aquifer System. Sci. Total Environ. 2019, 135845.

70. Gonçalves, R.D.; Engelbrecht, B.Z.; Chang, H.K. Evolução da contribuição do Sistema Aquífero Urucuia para o Rio São Francisco, Brasil. Águas Subterrâneas 2018, 32, 1-10.

71. Andrade, V.P.M.; da Silva, J.A.B.; de Sousa, J.S.C.; Oliveira, F.F.; Simões, W.L. Aspectos fisiológicos de videira submetida a manejos de irrigação e fertilização. Pesqui. Agropecu. Trop. 2017, 47, 390-398.

72. Preston, W.; do Nascimento, C.W.A.; da Silva, Y.J.A.B.; Silva, D.J.; Ferreira, H.A. Soil fertility changes in vineyards of a semiarid region in Brazil. J. Soil Sci. Plant Nutr. 2017, 17, 672-685.

73. Teixeira, A.H. de C. Determining Regional Actual Evapotranspiration of Irrigated Crops and Natural Vegetation in the São Francisco River Basin (Brazil) Using Remote Sensing and Penman-Monteith Equation. Remote Sens. 2010, 2, 1287-1319.

74. Budyko, M.I. Climate and life; Academic Press: New York, 1974;

75. Multsch, S.; Krol, M.S.; Pahlow, M.; Assunção, A.L.C.; Barretto, A.G.O.P.; de Jong van Lier, Q.; Breuer, L. Assessment of potential implications of agricultural irrigation policy on surface water scarcity in Brazil. Hydrol. Earth Syst. Sci. 2020, 24, 307-324. 